\title{
Bactericidal, bacteriolytic and opsonic activity of human serum against Escherichia coli
}

\author{
MAJA ROZENBERG-ARSKA, J. C. PORSIUS, EMMY Y. JAARSMA and J. VERHOEF \\ Department of Clinical Bacteriology and Laboratory of Microbiology, University Hospital, \\ University of Utrecht, Catharijnesingel 101, 3511 GV Utrecht, The Netherlands
}

\begin{abstract}
Summary. The effect of human serum on Escherichia coli was studied with serumsensitive and serum-resistant strains. The bactericidal effect of human serum on serumsensitive strains of $E$. coli depended on the activation of the classical complement pathway. The role of activation of the alternative pathway was less important. After incubation in sub-bactericidal concentrations of serum these strains were also easily phagocytosed by polymorphonuclear leukocytes (PMNL). Strains of $E$. coli of certain O-types required not only an intact classical pathway but also the presence of specific antibodies for effective killing by serum and effective phagocytosis by PMNL, despite rapid activation of complement and rapid deposition of $\mathrm{C} 3$ on the bacterial surface in the absence of antibody. Capsulate strains $01 \mathrm{~K} 1$ and $078 \mathrm{~K} 80$ resisted the bactericidal effect of serum even in the presence of specific antibodies; phagocytosis by PMNL only occurred after opsonisation with specific antibodies.
\end{abstract}

\section{Introduction}

The bacteriolytic activity of serum and the phagocytic capacity of leukocytes constitute important host defences against bacterial infections (Glynn and Howard, 1970; Klebanoff, 1975). Some gramnegative bacteria are sensitive to the lytic action of serum, whereas others are resistant (Taylor, 1983). The bactericidal effects of serum are mediated by the activated components of either the classical or the alternative complement pathway (Inoue et al., 1968; Forsgren et al., 1975; Fine, 1981). Activation of either pathway results in generation of the membrane attack complex (C5b-9), which is responsible for irreversible alterations in the structure of bacterial membranes leading to cell death (Goldman et al., 1969; Schreiber et al., 1979). Killing by serum is usually accompanied by bacteriolysis, which depends on adequate amounts of lysozyme (Inoue et al., 1959). Rough strains without $\mathrm{O}$ antigens are usually lysed in serum, smooth strains are often resistant (Joiner et al., $1982 a$ and $b$ ) and capsulate strains usually highly resistant (Howard and Glynn, 1971). The exact mechanism of resistance to serum killing of some gram-negative bacteria in the presence of adequate amounts of antibodies is still not well understood. In this study we compared the consumption and fixation of complement by different serum-sensitive and

Received 30 Sep. 1985; accepted 22 Nov. 1985. serum-resistant strains of $E$. coli and the rate of phagocytosis by polymorphonuclear leukocytes (PMNL) after opsonisation.

\section{Materials and methods}

\section{Bacterial strains}

Five non-capsulate strains-E. coli $\mathrm{O} 111$ and its uridine 5'-diphosphate(UDP)-galactose 4-epimerase-deficient mutant $E$. coli $\mathrm{J} 5(\mathrm{Rc}), E$. coli $\mathrm{O} 158$ (isolated from a stool culture), E. coli $\mathrm{K} 12: \mathrm{PC} 2166$, E. coli $\mathrm{O} 1: \mathrm{K}^{-}: \mathrm{H} 7$ (a spontaneous non-K1 mutant of $E$. coli $\mathrm{O} 1: \mathrm{K} 1: \mathrm{H} 7$ grown at $22^{\circ} \mathrm{C}$ ) - and two capsulate strains--E. coli $\mathrm{O} 78: \mathrm{K} 80$ (isolated from a blood culture) and E. coli $\mathrm{O} 1: \mathrm{K} 1: \mathrm{H} 7$ (isolated from a stool culture and kindly provided by $\mathrm{Dr}$ R. Bartolussi, Dalhousie University, Halifax, Nova Scotia) were used. $\mathrm{K}$ antigens were determined by the haemagglutination-inhibition technique of Glynn and Howard (1970). The $\mathrm{K} 1$ antigen was also detected by countercurrent immuno-electrophoresis (Robbins et al., 1974) with meningococcal group b antiserum (The Wellcome Research Laboratories, Beckenham, Kent).

\section{Radioactive labelling}

Strains of $E$. coli grown on a blood agar plate were seeded into $5 \mathrm{ml}$ of Mueller-Hinton Broth (Difco) containing $0.02 \mathrm{mCi}$ thymidine-methyl- ${ }^{3} \mathrm{H}(5 \mathrm{Ci} / \mathrm{mmol}$, sp.act; The Radiochemical Centre, Amersham, Bucks) and $1.25 \mathrm{mg}$ of deoxyadenosine (BDH Chemicals Ltd, Poole, Dorset). After incubation for $18 \mathrm{~h}$ at $37^{\circ} \mathrm{C}$, the bacteria were washed thrice with phosphate-buffered 
saline (PBS; $p \mathrm{H} \mathrm{7.4)} \mathrm{and} \mathrm{adjusted} \mathrm{to} \mathrm{a} \mathrm{final} \mathrm{concentration}$ of $10^{4} \mathrm{cfu} / \mathrm{ml}$ with a Klett-Summerson photoelectric colorimeter standardised by a pour-plate method (Verhoef et al. . 1977).

\section{Sera}

Normal human serum (NHS) from 10 healthy donors was pooled and stored in small portions at $-70 \mathrm{C}$. These sera were used as a source of human complement. Serum samples were thawed, only once, shortly before use. Inactivated serum (INHS) was obtained by heating NHS at $56 \mathrm{C}$ for $30 \mathrm{~min}$. In some experiments NHS was chelated with $10 \mathrm{~mm}$ ethylene glycol-bis ( $\beta$-aminoethyl ether-)- $N, N$-tetra-acetic acid (EGTA: Sigma Chemical Co.. St Louis, MO.) containing $10 \mathrm{~mm} \mathrm{MgCl}_{2}$ (Mg EGTA serum) (Forsgren et al., 1975).

For opsonisation of $E$. coli strain 0111 and strain $078: K 80$ antisera were prepared in rabbits with heat killed $E$. coli strain $O 111$ and formalin-killed $E$. coli strain O78:K80 (to preserve the $\mathrm{K}$ antigen) according to a method described by Van Dijk et al. (1981). Rabbit serum containing anti-human $\mathrm{C} 3 \mathrm{~b}$ was obtained from the Central Laboratory for Blood Transfusion (Amsterdam, The Netherlands). After isolation of immunoglobulins by $\left(\mathrm{NH}_{4}\right)_{2} \mathrm{SO}_{4}$ precipitation followed by separation on Sephadex G-25 fine (Pharmacia Fine Chemicals, Uppsala, Sweden), these antibodies were radiolabelled with $\mathrm{Na}^{125} \mathrm{~J}$ by using Jodogen (Pierce Chemical Co., Rockford, IL) according to Fraker and Speck (1978). Briefly, $2 \mathrm{mg}$ Jodogen (1,3,4,6-tetra-chloro-3a,6a-diphenyl-glycoluril; Pierce Chemical Co.) was dissolved in $20 \mathrm{ml}$ of chloroform, and $100 \mu$ of suspension was vapourised with dry nitrogen. Thereafter, $100 \mu \mathrm{l}$ of human anti $\mathrm{C} 3 \mathrm{~b}(10 \mathrm{mg} / \mathrm{ml}$ PBS) was added to the thin layer of the Jodogen, followed by addition of $500 \mu \mathrm{Ci} \mathrm{Na}{ }^{125} \mathrm{I}(13-17 \mathrm{mCi} / \mu \mathrm{g} \mathrm{sp}$.act; The Radiochemical Centre. Amersham). Labelling was performed at room temperature for $15 \mathrm{~min}$ and $\mathrm{Na}^{125} \mathrm{I}$ bound to anti $\mathrm{C} 3 \mathrm{~b}$ was separated from unbound $\mathrm{Na}^{125} \mathrm{I}$ on Sephadex G-25 fine (Pharmacia Fine Chemicals) in PBS containing $1 \%$ BSA as eluent. Portions of $500 \mu \mathrm{l}$ of ${ }^{125} \mathrm{I}$ antihuman $\mathrm{C} 3 \mathrm{~b}$ containing approximately ${ }^{125}{ }^{12} 10^{7} \mathrm{cpm} / \mu \mathrm{g}$ were kept frozen at $-20 \mathrm{C}$.

\section{Isolation of $P M N L$}

PMNL were isolated as previously described (Verhoef et al., 1977). Briefly, venous blood samples from healthy adult donors were drawn into heparinised syringes and allowed to settle by gravity in dextran (mol. wt 70,000; Pharmacia Fine Chemicals AB, Uppsala, Sweden) $6 \%$ in normal saline (blood $10 \mathrm{ml}$, saline $3 \mathrm{mil}$ ). The leukocyterich plasma was withdrawn and centrifuged at $160 \mathrm{~g}$ for $10 \mathrm{~min}$. The pellet was resuspended in Eagle's Minimal Medium: $16 \mathrm{ml}$ of the cell suspension was carefully layered on to $3 \mathrm{ml}$ of Ficoll-Paque (Pharmacia Fine Chemicals $\mathrm{AB}$ ) and centrifuged at $160 \mathrm{~g}$ for $35 \mathrm{~min}$. Mononuclear cells at the interface were removed. Residual erythrocytes in the pellet were lysed with ice-cold $\mathrm{NH}_{4} \mathrm{Cl} 0.87 \%$ in sterile water. After centrifugation at 160 $g$ for $15 \mathrm{~min}$, PMNL were washed twice in Hanks's Balanced Salts Solution with gelatin (Gel-HBSS). Leukocytes were adjusted to a concentration of $10^{7} \mathrm{PMNL} / \mathrm{ml}$ of Gel-HBSS (the percentage of monocytes in this suspension was always less than $3 \%$ ).

\section{Serum bactericidal assay}

Bacterial viability after incubation in various concentrations of NHS for various time intervals was compared with bacterial viability after incubation in INHS in HBSS. Briefly, $0.3 \mathrm{ml}$ of different strains of E. coli $\left(2 \times 10^{8}\right.$ $\mathrm{cfu} / \mathrm{ml}$ ) were mixed with $0.7 \mathrm{ml}$ of different concentrations of either NHS, MgEGTA-serum or INHS (in HBSS containing BSA $1 \%$ ). At various times thereafter, 100- $\mu \mathrm{l}$ samples were removed from the mixtures. Portions were serially diluted in HBSS with BSA $1 \%$ and plated on Brain Heart Infusion Agar (Difco) plates. After incubation for $18 \mathrm{~h}$ at $37^{\circ} \mathrm{C}$, the number of colonies was counted and extent of killing was expressed as the percentage of decrease in colony count compared with bacteria incubated in the same dilutions of INHS. Serum resistance was arbitrarily defined as $<20 \%$ reduction of the original bacterial inoculum after incubation for $60 \mathrm{~min}$ in NHS.

\section{Serum bacteriolytic assay}

Serum bacteriolysis was measured by determination of the release of $\left[{ }^{3} \mathrm{H}\right]$-thymidine from radiolabelled bacteria. Release of $\left[{ }^{3} \mathrm{H}\right]$-thymidine was measured by the method previously described (Rozenberg-Arska et al., 1984). Briefly, $0.3 \mathrm{ml}$ of $\left[{ }^{3} \mathrm{H}\right]$-thymidine-labelled strains of $E$. coli $\left(2 \times 10^{8} \mathrm{cfu} / \mathrm{ml}\right)$ was mixed either with $0.7 \mathrm{ml}$ of NHS $(10 \%)$ or with $0.7 \mathrm{ml}$ of MgEGTA-serum ( $10 \%$ and $50 \%$ ). After incubation for 15, 30,60 and $90 \mathrm{~min}$, tubes were removed from the water bath and placed on ice, followed by centrifugation at $12000 \mathrm{~g}$ for $10 \mathrm{~min}$. Radioactivity in supernate and sediment was measured in a liquid scintillation counter (Mark II Nuclear, Chicago, IL) after addition of $2.5 \mathrm{ml}$ scintillation fluid (Aqualuma Plus, Lumac Systems Inc., Titusville, FL). The percentage lysis was expressed as the percentage of radioactivity released from labelled bacteria into the supernate. $\left[{ }^{3} \mathrm{H}\right]$-thymidine labelled $E$. coli incubated in INHS was used as a control.

\section{Measurement of complement consumption}

To $0.1 \mathrm{ml}$ of bacterial suspension containing $5 \times 10^{8}$ $\mathrm{cfu} / \mathrm{ml}, 0.4 \mathrm{ml}$ of NHS or $10 \mathrm{~mm}$ MgEGTA-chelated serum $(10 \%)$ was added and incubated for various time intervals $(0,30,60$ and $90 \mathrm{~min})$. After incubation the total haemolytic complement remaining in the mixture was titrated with optimally sensitised sheep erythrocytes by the method of Mayer (1961). The consumption of complement in each test sample was expressed as a percentage of the haemolytic complement remaining in a control sample of serum incubated with buffer only. 
Fixation of C3b to strains of E. coli

Binding of $\mathrm{C} 3 \mathrm{~b}$ to the bacterial surface was measured indirectly with ${ }^{125} \mathrm{I}$-labelled anti-C3b. Different strains of E. coli were grown overnight in Mueller-Hinton Broth at $37^{\circ} \mathrm{C}$, centrifuged at $1400 \mathrm{~g}$ for $15 \mathrm{~min}$ and thereafter washed thrice in PBS. Sediments were resuspended in Gel-HBSS and adjusted to a concentration of $2 \times 10^{8} \mathrm{cfu} /$ $\mathrm{ml}$ with a Klett-Summerson photoelectric colorimeter. Mixtures of serum and bacteria were prepared as described above for the serum bactericidal assay and incubated for various time intervals. After centrifugation at $850 \mathrm{~g}$ for $15 \mathrm{~min}$ at $4^{\circ} \mathrm{C}$ bacteria were washed in GelHBSS. ${ }^{125}$ I-labelled anti-C3b (sp.act. $10^{7} \mathrm{cpm} / \mu \mathrm{g}$ ) prepared in Gel-HBSS was added to the bacterial sediments and incubated further for $30 \mathrm{~min}$ at room temperature. Mixtures were centrifuged and sediments were washed thrice with cold HBSS. The amounts of radioactivity associated with the pellets were counted in a PW 4800 automatic counter (Philips, Eindhoven, The Netherlands). Bacteria incubated in INHS were used as a control for nonspecific binding. The amount of $\mathrm{C} 3 \mathrm{~b}$ bound to bacterial surfaces was calculated as the percentage of maximally bound ${ }^{125} \mathrm{I}$.

\section{Opsonisation of strains of E. coli}

Bacteria were opsonised by incubating $10^{9} \mathrm{cfu} / \mathrm{ml}$ in various concentrations of serum for $30 \mathrm{~min}$ at $37^{\circ} \mathrm{C}$. Serum was removed by centrifugation $(15 \mathrm{~min}$ at $1600 \mathrm{~g})$ and bacteria were resuspended in Gel-HBSS to a final concentration of $5 \times 10^{8} \mathrm{cfu} / \mathrm{ml}$.

\section{Bacterial uptake}

Phagocytosis was assayed as previously described (Verhoef et al., 1977). Briefly, $0 \cdot 3 \mathrm{ml}$ of the suspension of opsonised $\left[{ }^{3} \mathrm{H}\right]$-thymidine-labelled bacteria $\left(5 \times 10^{8} \mathrm{cfu} /\right.$ $\mathrm{ml})$ was added to $0.3 \mathrm{ml}$ of PMNL $\left(10^{7}\right.$ cells $\left./ \mathrm{ml}\right)$ in polypropylene vials (Biovials, Beckman Instruments Inc., Fullerton, CA). For each bacterial strain 2 vials were used. Phagocytosis mixtures were incubated in a shaking waterbath at $37^{\circ} \mathrm{C}$. After $15 \mathrm{~min}$ phagocytosis was stopped by adding $3 \mathrm{ml}$ of ice-cold PBS to each of the vials. To determine leukocyte-associated radioactivity, the first vials containing different bacterial strains were centrifuged $\left(160 \mathrm{~g}\right.$ for $5 \mathrm{~min}$. at $\left.4^{\circ} \mathrm{C}\right)$, and leukocyte pellets were washed thrice with ice-cold PBS to remove nonleukocyte-associated bacteria and were suspended in 2.5 $\mathrm{ml}$ of scintillation fluid (Aqualuma Plus). To determine total radioactivity (representing leukocyte-associated plus non-leukocyte-associated bacteria), the remaining vials were centrifuged at $1600 \mathrm{~g}$ for $15 \mathrm{~min}$ and the pellets were resuspended in $2.5 \mathrm{ml}$ of scintallation liquid. Radioactivity was measured in a Mark II liquid scintillation counter (Nuclear Chicago Corp., Des Plaines, IL). Phagocytosis was expressed as the percentage uptake (after $15 \mathrm{~min}$ ) of total added radioactivity.

\section{Results}

Susceptibility to normal human serum and MgEGTA-chelated serum

The susceptibilities of $E$. coli strains PC2166, J5, $\mathrm{O} 111, \mathrm{O} 158, \mathrm{O} 78 \mathrm{~K} 80, \mathrm{O} 1 \mathrm{~K} 1$ and its mutant $\mathrm{O} 1 \mathrm{~K}^{-}$ were determined by incubating each strain for various times at $37^{\circ} \mathrm{C}$ in the presence of $10 \% \mathrm{NHS}$; bactericidal as well as bacteriolytic effect was studied. More than $96 \%$ of $E$. coli strain PC2166 and $E$. coli strain J5 were killed by $10 \%$ NHS after incubation for $30 \mathrm{~min}$ (table I). There was little killing of $E$. coli strain 0111 until it had been incubated for $30 \mathrm{~min}(<20 \%)$; however, after incubation for 60 and $90 \mathrm{~min}, 52 \%$ and $66 \%$ of the bacteria, respectively, were killed. In the presence of $10 \%$ serum containing specific antibodies to strain O $111,74 \%$ of bacteria were killed after incubation

Table I. Killing of non-capsulate and capsulate strains of $E$. coli by normal human serum (NHS) and by MgEGTA-chelated serum

\begin{tabular}{|c|c|c|c|c|}
\hline \multirow[b]{3}{*}{ Strain } & \multirow{3}{*}{$\begin{array}{l}\text { Incubation } \\
\text { time (min) }\end{array}$} & \multicolumn{3}{|c|}{ Percentage killing* in } \\
\hline & & \multirow{2}{*}{$\begin{array}{l}\text { NHS } \\
10 \%\end{array}$} & \multicolumn{2}{|c|}{ MgEGTA } \\
\hline & & & $10 \%$ & $50 \%$ \\
\hline \multirow{3}{*}{$\mathrm{PC} 2166$} & 30 & $>99.9$ & 4 & 23 \\
\hline & 60 & $>99.9$ & 9 & $96 \cdot 1$ \\
\hline & 90 & $>99.9$ & 15 & $>99.9$ \\
\hline \multirow{3}{*}{$\mathrm{J} 5$} & 30 & $96 \cdot 7$ & 3 & $48 \cdot 7$ \\
\hline & 60 & 99 & 5 & $74 \cdot 5$ \\
\hline & 90 & $99 \cdot 8$ & 8 & 97 \\
\hline \multirow{3}{*}{ O111† } & 30 & 18 & 0 & 0 \\
\hline & 60 & $52 \cdot 4$ & 0 & 0 \\
\hline & 90 & $66 \cdot 7$ & 0 & 0 \\
\hline \multirow{3}{*}{ O158 } & 30 & $59 \cdot 9$ & 0 & 0 \\
\hline & 60 & $55 \cdot 9$ & 0 & 0 \\
\hline & 90 & $41 \cdot 9$ & 0 & 0 \\
\hline \multirow{3}{*}{ O1K } & 30 & 83 & 0 & $23 \cdot 4$ \\
\hline & 60 & 82 & 0 & $44 \cdot 5$ \\
\hline & 90 & $81 \cdot 5$ & 0 & $87 \cdot 1$ \\
\hline \multirow{3}{*}{ OlK1 } & 30 & 5 & 0 & 0 \\
\hline & 60 & 7 & 0 & 0 \\
\hline & 90 & 7 & 0 & 0 \\
\hline \multirow{3}{*}{$078 \mathrm{~K} 80$} & 30 & 0 & 0 & 0 \\
\hline & 60 & 0 & 0 & 0 \\
\hline & 90 & 0 & 0 & 0 \\
\hline
\end{tabular}

* Percentage reduction of initial viable count; results shown are mean of three independent experiments.

$\dagger$ Incubation in $10 \%$ antiserum for 30 and 90 min resulted in $74 \%$ and $90 \%$ killing respectively. 
for $30 \mathrm{~min}$ and $85 \%$ after $90 \mathrm{~min}$. E. coli strain O158 was killed by $10 \%$ NHS during incubation for 30 min, but during further incubation bacterial growth was observed. In contrast, both capsulate $E$. coli strains $\mathrm{O} 1 \mathrm{~K} 1$ and $\mathrm{O} 78 \mathrm{~K} 80$ were resistant to the bactericidal activity of $10 \%$ NHS and appeared to multiply after incubation for $60-90 \mathrm{~min}$. The noncapsulate mutant $\mathrm{OlK}^{-}$appeared to be serumsensitive and was killed readily after incubation for $30 \mathrm{~min}$.

The addition of $10 \mathrm{~mm} \mathrm{MgEGTA} \mathrm{to} 10 \%$ NHS, a procedure that renders the classical pathway nonfunctional, inhibited the bactericidal activity (table I). However, $50 \%$ chelated NHS was bactericidal against $E$. coli strains $\mathrm{PC} 2166, \mathrm{~J} 5$ and $\mathrm{O} 1 \mathrm{~K}^{-}$. The rates of killing after incubation for $30 \mathrm{~min}$ were much slower than with $10 \%$ NHS. After $90 \mathrm{~min}$ there was practically no difference between $10 \%$ NHS and $50 \%$ MgEGTA-chelated serum (table I). $E$. coli strains $\mathrm{O} 111$ and $\mathrm{O} 158$ as well as both capsulate strains were not affected by chelated serum. Heating of NHS at $56 \mathrm{C}$ for $30 \mathrm{~min}$ or treatment with EDTA completely abolished bactericidal activity of serum.

To study the bacteriolytic effect of serum, the

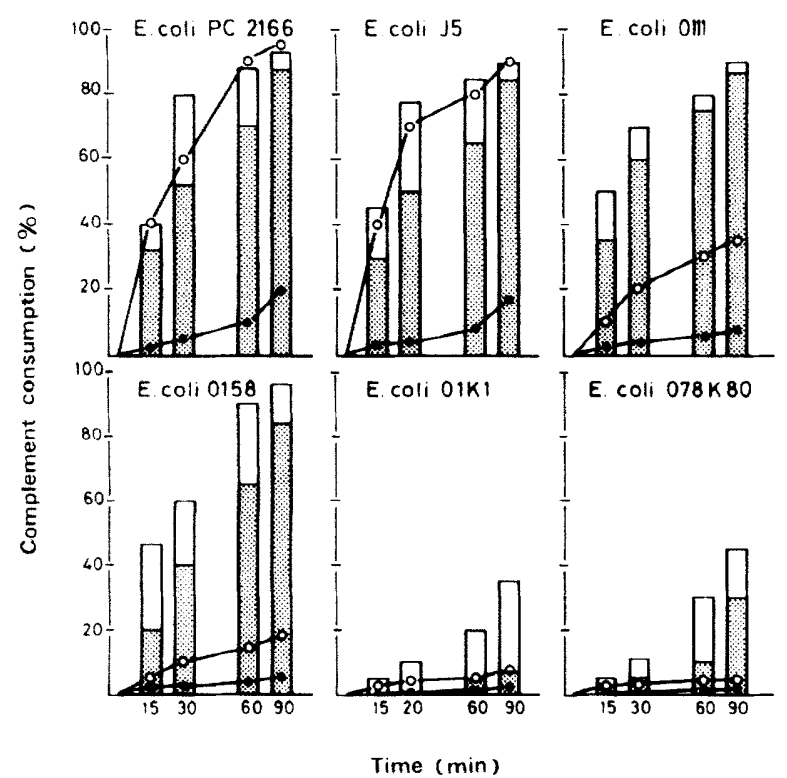

Fig. 1. Consumption of haemolytic complement by strains of $E$. coli and release of radioactivity from $\left[{ }^{3} \mathrm{H}\right]$-thymidine-labelled strains incubated in $10^{\circ}$ NHS and $10^{\circ}$. MgEGTA-chelated serum for various times. $\square$ represent consumption of complement in NHS, represent consumption of complement in $\mathrm{MgEGTA}$ serum: $\mathrm{O}-\mathrm{O}-\mathrm{O}$ represent radioactivity released into medium after incubation in NHS; and - represent radioactivity released into medium after incubation in $\mathrm{MgEGTA}$ treated serum. Results are expressed as percentages. percentage of radioactivity released from radiolabelled bacteria after exposure to $10 \%$ NHS or MgEGTA-chelated serum for various times was measured. Incubation of $\left[{ }^{3} \mathrm{H}\right]$-thymidine labelled $E$. coli strains PC2166 and J5 in NHS for $90 \mathrm{~min}$ resulted in release of $90 \%$ of the radioactivity from the bacteria into the medium (fig. 1). After incubation for $90 \mathrm{~min}$, only $35 \%$ and $20 \%$ radioactivity were released from $E$. coli strains 0111 and 0158 respectively. It is interesting that $E$. coli $\mathrm{O} 158$, which was more rapidly killed in serum than $E$. coli $\mathrm{O} 111$, released less radioactivity into the medium. This difference can probably be explained by growth of this strain in serum and it is possible that $E$. coli O158 incorporated thymidine during the growth. Both capsulate strains showed practically no release of radioactivity; however, the non-capsulate mutant $\mathrm{O}_{1} \mathrm{~K}^{-}$was lysed in $10 \%$ serum, resulting in $78 \%$ release of $\left[{ }^{3} \mathrm{H}\right]$-thymidine into the medium. Incubation of $E$. coli strains PC2166 and J5 in 10\% serum chelated with MgEGTA led to much lower release of radioactivity, which did not exceed $30 \%$ (fig. 1). The same results were obtained with $E$. coli OlK - (data not shown). Other strains of $E$. coli $(\mathrm{O} 111, \mathrm{O} 158, \mathrm{O} 1 \mathrm{~K} 1$ and $\mathrm{O} 78 \mathrm{~K} 80)$ did not show any substantial release of radioactivity (fig. 1). Heated and EDTA-treated serum caused no release of radioactivity from radiolabelled bacteria.

\section{Consumption of complement}

Consumption of $\mathrm{C} 3$ was examined in kinetic experiments in 10\% NHS and 10\% MgEGTAchelated serum (fig. 1). After 15, 30, 60 and $90 \mathrm{~min}$ the total haemolytic complement remaining in the mixtures was determined. All non-capsulate strains consumed complement rapidly and essentially reached an endpoint at $90 \mathrm{~min}$ with $85-95 \%$ consumption of $\mathrm{C} 3$ (fig. 1). Thus, these differences in killing of non-capsulate strains were not a consequence of inefficient complement activation. After incubation for $90 \mathrm{~min}$ both capsulate strains consumed only $35-50 \%$ of complement (fig. 1). When strains of $E$. coli were incubated in $10 \% \mathrm{MgEGTA}$ chelated serum, complement consumption was reduced (fig. 1).

\section{Binding of C3b to strains of $E$. coli}

Binding of $\mathrm{C} 3 \mathrm{~b}$ to the surface of different strains of $E$. coli during the incubation in NHS and MgEGTA-chelated serum was studied. Radioiodinated anti-human $\mathrm{C} 3 \mathrm{~b}$ was added to bacteria previously incubated in $10 \%$ NHS or $10 \%$ MgEGTA-chelated serum for various times and the 


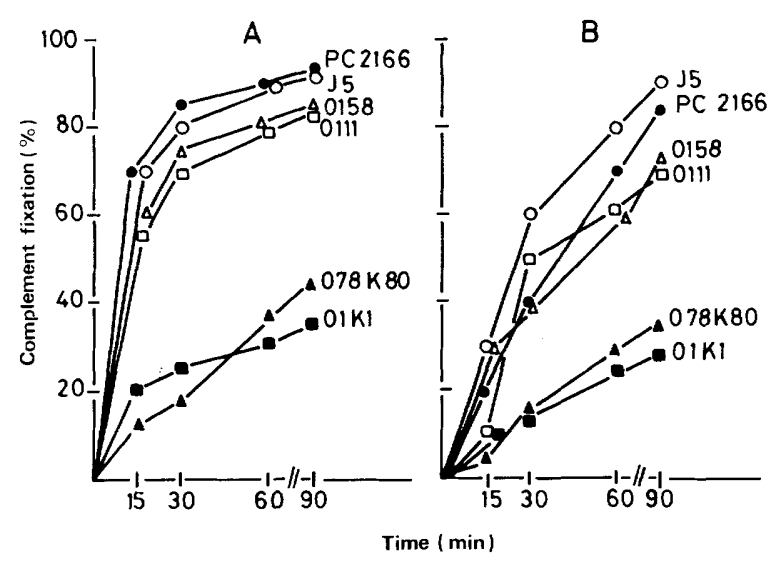

Fig. 2. Fixation of complement (C3) by strains of $E$. coli after incubation in $10 \% \mathrm{NHS}$ (A) and $10 \%$ MgEGTA-chelated serum (B). Points represent the mean of three independent experiments.

percentage of bound $\mathrm{C} 3 \mathrm{~b}$ calculated. With all noncapsulate strains more than $60 \%$ of $\mathrm{C} 3 \mathrm{~b}$ was bound after incubation for $15 \mathrm{~min}$, reaching an endpoint at 60 min with binding of $80-90 \%$ (fig. $2 \mathrm{~A}$ ). In contrast incubation of the capsulate $E$. coli strains $\mathrm{O} 1 \mathrm{~K} 1$ and O78K 80 in $10 \%$ NHS serum resulted in only 30 and $40 \%$ binding after $60 \mathrm{~min}$. Incubation of strains of $E$. coli in MgEGTA-chelated serum led to a slower rate of $\mathrm{C} 3 \mathrm{~b}$ binding than in normal human serum (fig. 2B).

Opsonisation of strains of E. coli in NHS and in MgEGTA-chelated serum

To study the opsonic requirement of strains PC2166, J5, O111, O158, O1K1, O1K ${ }^{-}$and O78K 80 the uptake of these strains by PMNL after incubation for $30 \mathrm{~min}$ in different concentrations of NHS and MgEGTA-chelated serum was measured. E. coli strains $\mathrm{PC} 2166, \mathrm{~J} 5$ and $\mathrm{O} 158$ were easily opsonised in $5 \%$ NHS showing 90,90 and $84 \%$ uptake respectively (table II). E. coli strain 0111 differed from other non-capsulate strains as opsonisation in $5 \%$ NHS did not lead to phagocytosis (table II), whilst incubation in $5 \%$ specific antiserum resulted in $56 \%$ uptake. Capsulate strains O1K1 and O78K80 were not efficiently opsonised in NHS; after opsonisation in $20 \%$ NHS uptake by PMNL was only $25 \%$ and $9 \%$ respectively (table II). Opsonisation of E. coli strain $\mathrm{O} 78 \mathrm{~K} 80$ in $20 \%$ specific antiserum resulted in $55 \%$ phagocytosis by PMNL. To determine if $\mathrm{K}$ antigen reduced the ability of $E$. coli to be opsonised in NHS, E. coli strain $078 \mathrm{~K} 80$ was heated for $15 \mathrm{~min}$ at $80^{\circ} \mathrm{C}$. After the destruction of $\mathrm{K}$ antigen $E$. coli $\mathrm{O}^{-} \mathrm{K}^{-}$was readily opsonised in $5 \%$ NHS and phagocytosed at
Table II. Phagocytosis by PMNL of strains of $\boldsymbol{E}$. coli opsonised in NHS or MgEGTA-chelated serum $\dagger$

\begin{tabular}{|c|c|c|c|c|c|c|}
\hline \multirow[b]{3}{*}{ Strains } & \multicolumn{6}{|c|}{$\begin{array}{l}\text { Percentage phagocytosis* } \\
\text { of } E \text {. coli opsonised in }\end{array}$} \\
\hline & \multicolumn{3}{|c|}{ NHS } & \multicolumn{3}{|c|}{ MgEGTA } \\
\hline & $2.5 \%$ & $5 \%$ & $20 \%$ & $2.5 \%$ & $5 \%$ & $20 \%$ \\
\hline PC2166 & 80 & 90 & ND & 40 & 65 & ND \\
\hline $\mathrm{J} 5$ & 85 & 90 & ND & 45 & 60 & ND \\
\hline O111 & 0 & 5 & ND & 0 & 0 & ND \\
\hline $0158^{\circ}$ & 78 & 84 & ND & 5 & 10 & ND \\
\hline $\mathrm{O}^{\prime} \mathrm{K}^{-}$ & 85 & 97 & ND & 50 & 72 & ND \\
\hline O78K $\mathrm{K}^{-}$ & 35 & 78 & ND & 24 & 35 & ND \\
\hline OIK 1 & 0 & 17 & 25 & 0 & 9 & 15 \\
\hline O78K $80 \$$ & 0 & 4 & 9 & 0 & 0 & 4 \\
\hline
\end{tabular}

\footnotetext{
* Mean of three determinations.

$\uparrow$ Preparation consisted of $10^{7} \mathrm{PMN} / \mathrm{ml}$ and $5 \times 10^{8}$ bacteria $/ \mathrm{ml}$ previously opsonised in serum for $30 \mathrm{~min}$. Phagocytosis mixtures were incubated for $15 \mathrm{~min}$ at $37^{\circ} \mathrm{C}$.

$\ddagger$ Opsonisation in $5 \%$ antiserum resulted in $56 \%$ phagocytosis.

$\S$ Opsonisation in $20 \%$ antiserum resulted in $55 \%$ phagocytosis.
}

a rate of $78 \%$. Also the non-capsulate mutant $\mathrm{O} \mathrm{K}^{-}$was very well opsonised in $5 \%$ NHS, which resulted in $97 \%$ uptake by PMNL.

Opsonisation in 5\% MgEGTA-chelated serum led to 65 and $60 \%$ uptake of $E$. coli strains PC2166 and J5. E. coli strain O158 showed only $10 \%$ uptake when opsonised in 5\% MgEGTA serum, but opsonisation in $5 \%$ NHS led to $84 \%$ uptake; $5 \%$ MgEGTA serum did not opsonise E. coli 0111 . Both encapsulated strains showed minimal uptake when opsonised even in $20 \%$ MgEGTA serum.

\section{Discussion}

Previously we have shown that some strains of $E$. coli lose viability and often become degraded when exposed to NHS (Van Dijk et al., 1981; RozenbergArska et al., 1984). Capsulate strains and also strains of certain O-types appeared resistant to the bactericidal and bacteriolytic action of serum. Complement was required for killing by NHS, since treatment of NHS at $56^{\circ} \mathrm{C}$ for 30 min abolished all bactericidal activity. Optimal serum bactericidal activity required an intact classical pathway of complement and the presence of antibodies. However, 50\% MgEGTA-chelated serum also lysed and killed E. coli strains PC2166 and J5 and the noncapsulate mutant $\mathrm{O} 1 \mathrm{~K}^{-}$. This indicates that certain 
strains of $E$. coli can also be killed by the alternative pathway of complement activation. However, the rate of killing in $50 \%$ MgEGTA serum was very slow despite the fact that these gram-negative rods were able to activate the alternative complement pathway rapidly. In contrast, activation of the classical pathway of complement by these strains correlated very well with killing and fixation of $\mathrm{C} 3 \mathrm{~b}$ by the bacterial surface. Similar results were obtained by Roberts and Phillips (1981, 1983) who showed that strains of $E$. coli of the common urinary $\mathrm{O}$-serogroups differ widely in their sensitivity to NHS.

It is possible that this slow rate of killing or lysis in MgEGTA serum is due to some remaining activity of the classical pathway. Strains of certain O-types such as E. coli $\mathrm{O} 111$ and $E$. coli $\mathrm{O} 158$ were killed very slowly when incubated in NHS, and this effect was completely abolished by MgEGTAchelated serum. These strains required an intact classical pathway and the presence of antibodies for killing by serum. The presence of specific antibodies directed against $\mathrm{O}$ antigens enhanced the bactericidal effect of NHS. It has been suggested that long $\mathrm{O}$-antigenic polysaccharide chains associated with lipopolysaccharides cause antibody-mediated activation of complement too far from the target site (Rowley, 1973). There were no essential differences in complement consumption and complement fixation between serum-sensitive strains of $E$. coli killed quickly and those killed only slowly. Joiner et al. (1982a and $b$ ) showed that serum-sensitive and serum-resistant strains of Salmonella minnesota consumed complement during incubation in serum and deposition of membrane-attack complex on the surfaces of both strains was observed. However, serum-resistant $S$. minnesota was not killed by serum despite rapid complement consumption and rapid deposition of membrane-attack complex on the bacterial surface. The deposition of C $5 b-9$ on the cell surface was not stable; it was released from the bacterial surface without causing lethal outer membrane damage (Joiner et al., 1982a and $b$ ). It was also shown by these authors that addition of bactericidal antibodies did not change the rate of complement deposition on the cell surface but increased the bactericidal efficiency of complement factors (e.g., with $E$. coli O111). Thus, bactericidal

\section{REFERENCES}

Fine D P 1981 Complement and infectious diseases. CRC Press. Inc., Boca Raton, FL. pp 43-84. antibodies were not needed for complement consumption and fixation, but they were necessary for efficient killing of certain $\mathrm{O}$ types of $E$. coli, perhaps forming IgG-C3b complexes (Joiner et al., 1983a and $b$ ). It is also possible that outer-membrane proteins are involved. Our results showed that both capsulate strains $\mathrm{O} 1 \mathrm{Kl}$ and $078 \mathrm{~K} 80$ resisted the bactericidal effect of serum as well as phagocytosis by PMNL in the absence of specific antibodies. This effect was attributed to the presence of a capsule, which blocked complement consumption and binding of C3b by masking surface components such as lipopolysaccharides capable of activating the complement pathway. To assess the role of the capsule, a spontaneous mutant without $\mathrm{K} 1$ capsular antigen and $E$. coli $\mathrm{O} 78 \mathrm{~K} 80$ after heat destruction of $\mathrm{K}$ antigen were studied. Both strains were able to activate complement and to bind C3 molecules (although, we cannot exclude the possibility that heating of $E$. coli $\mathrm{O} 78 \mathrm{~K} 80$ affects also other cellenvelope components). The non-capsulate $\mathrm{OlK}^{-}$ mutant was killed and lysed in NHS as well as in MgEGTA-chelated serum and both strains were readily phagocytosed. It was shown by Howard and Glynn (1971) that the state of capsulation of the bacteria and the kind of capsular antigens are important determinants of their capacity to bind complement. The amount of capsular material may vary in different strains and may also vary with different culture conditions. In general, when noncapsulate strains of $E$. coli encounter serum, their lipopolysaccharide-rich outer-membrane promotes complement fixation to the bacterial surface. Consequently the bacteria are either lysed by serum or ingested and removed by PMNL. When some noncapsulate strains of $E$. coli of certain O-types and capsulate strains encounter serum, complement is not fixed to the bacterial surface in the absence of specific antibacterial antibodies. Consequently, these strains resist lysis by complement and resist phagocytosis; this may account for enhanced pathogenicity of those bacteria. When specific antibodies are available, complement is bound and the resistant bacteria are either lysed or phagocytosed.

We thank Dr J. Schellekens for critically reviewing this manuscript and Miss Y. Joseph and Mrs A. McArthur-Noom for secretarial assistance.
Forsgren A, Mclean R H, Michael A F, Quie P G 1975 Studies of the alternative pathway in chelated serum. Journal of Laboratory and Clinical Medicine 85:904-912.

Fraker P J, Speck J C 1978 Protein and cell membrane 
iodinations with a sparingly soluble chloroamide, 1, 3, 4, 6tetrachloro-3a,6a-diphenylglycoluril. Biochemical and Biophysical Research Communications 80:849-857.

Glynn A A, Howard C J 1970 The sensitivity to complement of strains of Escherichia coli related to their $\mathrm{K}$ antigens. Immunology 18:331-346.

Goldman J N, Ruddy S, Austen K F, Feingold D S 1969 The serum bactericidal reaction. III. Antibody and complement requirements for killing a rough Escherichia coli. Journal of Immunology 102:1379-1387.

Howard C J, Glynn A A 1971 The virulence for mice of strains of Escherichia coli related to the effects of $\mathbf{K}$ antigens on their resistance to phagocytosis and killing by complement. Immunology 20:767-777.

Inoue K, Tanigawa Y, Takubo M, Satani M, Amano T 1959 Quantitative studies on immune bacteriolysis. II. The role of lysozyme in immune bacteriolysis. Biken Journal 2:1-20.

Inoue K, Yonemasu K, Takamizawa A, Amano T 1968 Studies on the immune bacteriolysis. XIV. Requirement of all nine components of complement for immune bacteriolysis. Biken Journal 11:203-206.

Joiner K A, Goldman R C, Hammer C H, Leive L, Frank M M 1983a Studies of the mechanism of bacterial resistance to complement-mediated killing. V. IgG and $F\left(a b^{\prime}\right)_{2}$ mediate killing of $E$. coli O111B4 by the alternative complement pathway without increasing C5b-9 deposition. The Journal of Immunology 131:2563-2569.

Joiner K A, Goldman R C, Hammer C H, Leive L, Frank M M 1983b Studies on the mechanism of bacterial resistance to complement-mediated killing. VI. IgG increases the bactericidal efficiency of C5b-9 for E. coli O111B4 by acting at a step before $\mathrm{C} 5$ cleavage. The Journal of Immunology 131:2570-2575.

Joiner K A, Hammer C H, Brown E J, Cole R J, Frank M M 1982a Studies on the mechanism of bacterial resistance to complement-mediated killing. I. Terminal complement components are deposited and released from Salmonella minnesota S218 without causing bacterial death. Journal of Experimental Medicine 155:797-808.

Joiner K A, Hammer C H, Brown E J, Frank M M 1982b Studies on the mechanism of bacterial resistance to complementmediated killing. II. C8 and $\mathrm{C} 9$ release $\mathrm{C} 5 \mathrm{~b} 67$ from the surface of Salmonella minnesota S218 because the terminal complex does not insert into the bacterial outer membrane. Journal of Experimental Medicine 155:809-819.
Klebanoff S J 1975 Antimicrobial systems of the polymorphonuclear leukocyte. In: Bellanti J A, Dayton D H (eds) The phagocytic cell in host resistance, Raven Press, New York, $p$ 45-59.

Mayer M M 1961 Complement and complement fixation. In: Kabat E A, Mayer M M (eds) Experimental immunochemistry, 2nd edn. Charles C. Thomas, Springfield, IL, pp $133-240$.

Robbins J B, McCracken G H, Gotschlich E C, Ørskov F, Ørskov I, Hanson L A 1974 Escherichia coli Kl capsular polysaccharide associated with neonatal meningitis. New England Journal of Medicine 290:1216-1220.

Roberts A P, Philips R 1981 The effects of ethyleneglycoltetraacetic acid on bactericidal activity of human serum against Escherichia coli. Journal of Medical Microbiology 14:195203.

Roberts A P, Phillips R 1983 The relative importance of the classical and alternative complement pathway in serum bactericidal activity against Escherichia coli. Journal of Medical Microbiology 16:69-74.

Rowley D 1973 Antibacterial action of antibody and complememt. Journal of Infectious Diseases 128 (Suppl): S170. S175.

Rozenberg-Arska M, Salters E C, van Strijp J A, Hoekstra W P M, Verhoef J 1984 Degradation of Escherichia coli chromosomal and plasmid DNA in serum. Journal of General Microbiology 130:217-222.

Schreiber R D, Morrison D C, Podack E R, Müller-Eberhard $\mathrm{HJ} 1979$ Bactericidal activity of the alternative complement pathway generated from eleven isolated plasma proteins. Journal of Experimental Medicine 149:870-882.

Taylor P W 1983 Bactericidal and bacteriolytic activity of serum against gram-negative bacteria. Microbiological Reviews 47:46-83.

Van Dijk W C, Verburgh H A, van Erne-van der Tol M E, Peters R, Verhoef J 1981 Escherichia coli antibodies in opsonisation and protection against infection. Journal of Medical Microbiology 14:381-389.

Verhoef J, Peterson P K, Quie P G 1977 Kinetics of Staphylococcal opsonization, attachment, ingestion and killing by human polymorphonuclear leukocytes: a quantitative assay using $\left[{ }^{3} \mathrm{H}\right]$ thymidine labeled bacteria. Journal of Immunological Methods 14:303-311. 